\title{
CINNSEL SUÇLAR, Türk Ceza Kanununun Cinsel Suçlara İlişkin Düzenlemelerinin Dayandığı Felsefi Temel, Cinsel Suçlara İlişsin Kanun Hükümlerinin Uygulanmasından Kaynaklanan Sorunlar
}

\author{
İzzet ÖZGENÇ*
}

\section{$\ddot{O} Z$}

Türk Ceza Kanununda yer alan cinsel suçlara ilişkin düzenlemelerin dayandiğı felsefi yaklaşım esas alınmadan uygulama geliştirilmesinin, çeşitli sorunlara sebebiyet vereceği kaçınılmaz bir gerçektir. Doğru bir uygulama gerçekleştirebilmek için, öncelikle, cinsel suçlara ilişkin düzenlemelerin dayandı̆̆ felsefi yaklaşımı ortaya koymak gerekir. Bu yaklaşım sorunu dolayısıyladır ki, yüksek mahkeme içtihatlarında cinsel davranışlara yönelik rızanın cinsel suçlar bakımından bir "hukuka uygunluk sebebi" oluşturduğu yönündeki yanlış gerekçelendirmelere devam edilmektedir. Keza, bir kusurluluğu etkileyen ve hatta bazı durumlarda ortadan kaldıran sebep olarak haksızlık hatasına ilişkin kanun hükümlerinin özellikle cinsel suçlar bakımından uygulanmasındaki çekingenlik, ortaya bir dizi sorunlu mahkumiyet hükmü ve hükümlü sorunu çıkarmıştır.

Bu sorunların TCK'nın mevcut hükümleri çerçevesinde geliştirilen içtihatlarla çözümlenmesi mümkün ve gerekirken, söz konusu çekingenlik, yasama faaliyetiyle, yani geçici madde şeklinde de olsa, kanuni düzenlemeyle "çözümlenmesi”" çabalarını tetiklemiştir.

Çalışmamızda, özellikle cinsel istismar suçunun mağduru ile failinin bilahare "evlendirilmeleri" bağlamında ortaya çıkan sun' $\hat{\imath}$ "sorunun” kanuni düzenlemeyle “çözümlenmesine” çalışılmasının yanlışlığına ve doğru çözüme ilişkin açıklamalarda bulunulmuştur.

Anahtar Kelimeler: Cinsel dokunulmazlı, Cinsel saldırl, Cinsel istismar, Cinsel taciz, Cinsel davranış, Cinsel ilişki, Evlenme engeli, Evlenme yasağı

* Prof.Dr., Ankara Hacı Bayram Veli Üniversitesi Hukuk Fakültesi Ceza ve Ceza Muhakemesi Anabilim Dalı Öğretim Üyesi.

ORCID ID: 0000-0002-1805-8572

DOI : 10.34246/ahbvuhfd.682799

Yayın Kuruluna Ulaştığı Tarih $\quad$ : 12/12/2019

Yayınlanmasının Uygun Görüldüğü Tarih: 09/01/2020

Ankara Hacı Bayram Veli Üniversitesi Hukuk Fakültesi Dergisi C. XXIV, Y. 2020, Sa. 1257 
SEXUAL OFFENCES,

\title{
The Philosophical Basis on which the Turkish Penal Code Regulations on Sexual Offences, Problems arising from the application of the provisions of the Codes about Sexual Offences
}

\begin{abstract}
It's an inevitable fact that developing a practice without considering the philosophical approach on which regulations related to the sexual offences in the Turkish Penal Code are based would cause various problems. In order to provide a correct implementation, first of all, it is necessary to examine the philosophical approach on which the regulations on sexual offences are grounded. It is due to this approachrelated problem that the wrong justification in the Court of Cassation's case-law that the consent to sexual behavior constitutes a "justification defense" for sexual offences still continues. Likewise, timidity in the application of the provision on the mistake of law, which is an excuse defense that removes or mitigates the culpability of the actor, especially in respect to sexual offences has given rise to several problematic convictions.
\end{abstract}

Although it is possible and necessary to solve these problems with the case-law developed pursuant to the current provisions of the Turkish Penal Code, aforementioned hesitancy has triggered efforts to "resolve" these problems through legislative action -in other words, by means of legal regulation, even in the form of provisional article-.

In this article, there are explanations with regard to the incorrectness of trying to "solve" the factitious "problem", which occurs within the context of "wedding" the victim of the sexual abuse of children to the perpetrator of the offence, through legal regulation, and about the correct solution.

Keywords: Sexual inviolability, Sexual assault, Sexual abuse of children, Sexual harassment, Sexual behavior, Sexual intercourse, Impediment to marriage, Prohibition for marriage

\section{Giriş:}

Türk Ceza Kanununda yer alan cinsel suçlara ilişkin düzenlemelerin dayandığı felsefi yaklaşım esas alınmadan uygulama geliştirilmesinin, çeşitli sorunlara sebebiyet vereceği kaçınılmaz bir gerçektir. Doğru bir uygulama gerçekleştirebilmek için, öncelikle, cinsel suçlara ilişkin düzenlemelerin dayandığı felsefi yaklaşımı ortaya koymak gerekir. Bu yaklaşım sorunu 
dolayısıyladır ki, yüksek mahkeme içtihatlarında cinsel davranışlara yönelik rızanın cinsel suçlar bakımından bir "hukuka uygunluk sebebi" oluşturduğu yönündeki yanlış gerekçelendirmelere devam edilmektedir. Keza, bir kusurluluğu etkileyen ve hatta bazı durumlarda ortadan kaldıran sebep olarak haksızlık hatasına ilişkin kanun hükümlerinin özellikle cinsel suçlar bakımından uygulanmasındaki çekingenlik, ortaya bir dizi sorunlu mahkumiyet hükmü ve hükümlü sorunu çıkarmıştır.

$\mathrm{Bu}$ sorunların TCK'nın mevcut hükümleri çerçevesinde geliştirilen içtihatlarla çözümlenmesi mümkün ve gerekirken, söz konusu çekingenlik, yasama faaliyetiyle, yani geçici madde şeklinde de olsa, kanuni düzenlemeyle "çözümlenmesi”" çabalarını tetiklemiştir.

I. Anayasa Mahkemesinin 10.10.2019 tarihli ve 2015/17914 başvuru numaralı Bireysel Başvuru Kararına (RG: 27 Kasım 2019/30961) konu teşkil eden olayda; M, teyzesi T ile eniştesi E arasında Babaeski Asliye Hukuk Mahkemesinde görülmekte olan boşanma davasında tanık olarak dinlenir. M, bu tanıklık açıklamaları sırasında, E tarafından, çocukluk yaşlarından beri, henüz on dört yaşını doldurmadan önce başlayan, müteaddit defa tekrarlanan, cinsel arzularının tatmini amacına yönelik muameleye maruz bırakıldığını beyan eder.

M, bu açıklamaları çerçevesinde, henüz on dört yaşını doldurmamış olduğu bir zamanda T'nin daveti üzerine gittiği İstanbul'daki evlerinde kaldığı on beş gün kadar devam eden misafirlik sürecinde, E'nin cinsel birleşmeye varmayan ve fakat, fiziki temasla gerçekleştirdiği çeşitli cinsel davranışlarına müteaddit defa maruz kaldığını ve her defasında fiili gerçekleştirdikten sonra, E’nin kendisine "bu yaşadıklarımızı kesinlikle teyzene anlatma, yoksa seni yaşatmam" gibi sözler söylediğini beyan eder.

Keza M, memleketine döndükten sonra da, E'nin müteaddit defa telefonla arayarak kendisiyle, cinsel arzularını tatmin amacına yönelik cinsel içerikli sohbetler yaptı̆̆ını ve bu sohbetlerden sonra kendisine "konuştuklarımızı başkasına anlatırsan seni yaşatmam" gibi sözler söylediğini beyan eder.

M, on dört yaşını tamamladığı bir zamanda, T ve E'nin memleketlerine gelerek kendilerine misafir olduğunu, bu süre zarfında da E'nin cinsel arzularını tatmin amacına yönelik olan ve fakat cinsel birleşmeye varmayan fiillerine maruz kaldığını beyan eder.

M, yaptığg tanıklıkta bütün bu olup bitenleri annesi A'ya anlattığını söyler. 
Ancak, bu olaylarla ilgili olarak daha önce adlî mercilere herhangi bir ihbar ve şikâyette bulunulmaz.

Bu olay nedeniyle psikolojisi bozulan $\mathrm{M}$, eğitimine devam edemez.

II. 5237 say1lı Türk Ceza Kanununun sisteminde cinsel suçlara ilişkin düzenlemeler yapılırken, bazı temel kabullerden yola çıkılmıştır. Bu temel kabuller sırasıyla şunlardır:

1. Kanunda, tanımlanan cinsel suçlar bağlamında korunan hukuki değer, kişilerin cinsel dokunulmazlığı olarak belirlenmiştir. Bu bağlamda Kanunda "cinsel özgürlük" ibaresi kullanılmamıştır. Bu, bilinçli bir tercihtir.

Buna göre, kişiler cinsel arzularının tatmini amacıyla başkalarının vücut dokunulmazlığını ihlâl edemezler. Kişiler, cinsel arzularını tatmin etmeye yönelik partnerini belirlerken, fizikî ve ruhî gelişmişlik düzeyi, cinsiyet, akrabalık ilişkisi ve medeni hal gibi bazı doğal ve hukuki sınırlama ölçütlerine riayet etmekle yükümlü kılınmıştır. Bu sınırlama ölçütlerine riayet edilmemesi, cinsel arzuların tatmini amacına yönelik fiili hukuka aykırı kılmakla birlikte, bu bağlamdaki her hukuka aykırı fiil, ceza hukuku sorumluluğunu gerektirmez, yani suç oluşturmaz.

2. Keza, Türk Ceza Kanunundaki cinsel suçlara ilişkin düzenlemelerde, ilgili suçun işlenişi bakımından fail veya mağdurun erkek veya kadın olması bir ayırım ölçütü olarak dikkate alınmamıştır.

Mağdurun çocuk olup olmaması, cinsel saldırı suçu (TCK, m. 102) ile cinsel istismar suçu (TCK, m. 103) arasındaki ayırımın temel ölçütü olarak kabul edilmiştir.

3. Cinsel saldırı suçu (TCK, m. 102) ile cinsel taciz suçu (TCK, m. 105) arasındaki ayırımın temel ölçütünü, fiziksel temas oluşturmaktadır.

Cinsel istismar suçu (TCK, m. 103) bakımından ise, fiziksel temasın gerekli olup olmadığ 1 tartışmalı hale gelmiştir.

Bir anlayış, alelıtlak fiziksel temasa gerek olmadan cinsel istismar suçunun işlenebileceğini kabul etmektedir. Buna göre, on beş yaşını tamamlamamış olan veya tamamlamış olmakla birlikte zihinsel gelişiminde sorun bulunan çocuklara karşı fiziksel temas olmadan gerçekleştirilen cinsel davranışlar da cinsel istismar suçunu oluşturacaktır. Türk Ceza Kanununun cinsel suçlara ilişkin ilk düzenlemelerinde bu düşünce esas alınmıştı. 
İkinci bir anlayış ise, cinsel istismar suçunun da cinsel saldırı suçu gibi ancak mağdurun bedenine fiziksel temasta bulunmak suretiyle gerçekleştirilen cinsel davranışlarla işlenebileceğini kabul etmektedir. Bu anlayışa göre, yaşı ne olursa olsun, çocuğa karşı fiziksel temas olmadan gerçekleştirilen cinsel davranışlar ancak cinsel taciz suçunun nitelikli halini oluşturur. $\mathrm{Bu}$ itibarla, henüz on beş yaşını tamamlamamış olan çocuğa karşı fiziksel temas olmaksızın gerçekleştirilen cinsel davranışlar, cinsel istismar suçunu değil, cinsel taciz suçunu oluşturacaktır. Türk Ceza Kanununun cinsel suçlara ilişkin hükümlerinde değişiklik yapan 18.6.2014 tarihli ve 6545 sayılı Kanununun hazırlanışında bu düşünce egemen olmuştur. Nitekim, söz konusu Kanunun, TCK, m. 102'de değişiklik yapan 58. maddesinin gerekçesinde;

"Türk Ceza Kanununun 102 ve 103 'üncü maddelerinde tanımlanan suçların temel şekli ile 105 'inci maddesinde tanımlanan cinsel taciz suçu arasındaki ayırım ölçütü, fiziksel temastır. 105 'inci maddede tanımlanan suçun oluşabilmesi için mağdurun vücuduna fiziksel bir temas söz konusu değildir. Buna karşıllk, cinsel arzuların tatmini amacına yönelik olarak mağdurun vücuduna fiziksel temasta bulunulması halinde, mağdurun çocuk olup olmamasına göre 102 veya 103 'üncü maddede tanımlanan suçlardan biri oluşmaktadır"

yönünde açıklamaya yer verilmiştir ${ }^{1}$.

Kanaatimizce, 6545 say1lı Kanununla TCK, m. 105, f. 1'de yapılan değişiklikten sonra, orta bir yol izlemek gerekir.

Türk Ceza Kanununda "on beş yaşını tamamlamamış veya tamamlamış olmakla birlikte fïlin hukuki anlam ve sonuçlarını algılama yeteneği gelişmemiş olan çocuklara karşı gerçekleştirilen her türlü cinsel davranış" ve keza, on beş yaşını tamamlamış olan ve maruz kaldığı fiilin hukuki anlam ve sonuçlarını algılama yeteneği gelişmiş olan "çocuklara karşı sadece cebir, tehdit, hile veya iradeyi etkileyen başka bir nedene dayalı olarak gerçekleştirilen cinsel davranışlar", cinsel istismar olarak değerlendirilmiştir (TCK, m. 103, f. 1) $)^{2}$.

1 TBMM, Yasama Dönemi: 24, Yasama Y1lı: 4, Sıra Sayıs1: 592, sh. 20 vd.

2 Yargitay 14. Ceza Dairesinin 7.1.2019 tarihli ve E. 2015/3907, K. 2019/25 sayıl1 Kararına konu teşkil eden olayda; A ve B, çocuk olan mağdureyi sevk ve idarelerindeki araçla kaçırırlar. Olay yerinde A araç dışında beklerken, B mağdureye soyunmasını söyler. Bunun üzerine mağdure kıyafetlerini çıkarmaya başlar ve bu arada B mağdurenin fotoğrafını çekmeye çalışır. Ancak bu arada polisin olaya müdahale eder. 
İlk derece mahkemesi A ve B hakkında çocuğun nitelikli cinsel istismarı ve kişiyi hürriyetinden yoksun kılma suçlarından mahkumiyet hükmü kurmuştur.

Yargitay 14. Ceza Dairesi, bu olayda A ve B'nin fiillerinin "5237 sayıl TCK'nın 105. maddesinde düzenlenen cinsel taciz suçunu oluşturduğu, bu suçun soruşturma ve kovuşturmastnın şikayete tabi olduğu ve mağdurenin kovuşturma evresinde sanıklardan şikayetçi olmadlğını belirtmesi karşısında; vaki şikayet yokluğu nedeniyle kamu davasının düşmesine karar verilmesi gerekirken, yargılamaya devamla yazılı şekilde mahkûmiyet hükmü kurulması"nı, Kanuna aykırı bulmuştur.

\section{Hukuki değerlendirmelerimiz:}

Karara konu teşkil eden olayda işlenen suçlar, temel şekli ve nitelikli unsurları itibarıyla şunlardır:

Birinci suç: A + B $\rightarrow$ M’ye karşı, Kişiyi hürriyetinden yoksun kılma suçu (TCK, m. 109). Bu suç, birden fazla kişi tarafından birlikte işlenmiştir. Nitelikli unsur (TCK, m. 109, f. 3, bent b).

Suçun mağduru çocuktur. Nitelikli unsur (TCK, m. 109, f. 3, bent f).

Ayrıca, bu suç cinsel amaçla işlenmiştir. Nitelikli unsur (TCK, m. 109, f. 5).

İkinci suç: $\mathrm{A}+\mathrm{B} \rightarrow$ M'ye karşı, Çocuğun cinsel istismarı suçu (TCK, m. 103).

Bu suç, birden fazla kişi tarafından birlikte işlenmiştir. Nitelikli unsur (TCK, m. 109, f. 3, bent b).

Karar metninden, açıkça anlaşılmamakla birlikte, fiilin işlendiği tarih itibarıyla çocuğun on beş yaşını tamamlamış olduğu sonucu çıkarılmaktadır.

Henüz 15 yaşını tamamlamamış çocuğa karşı işlenen cinsel amaçlı -fiziki temas olsun veya olmasın- bütün fiillerin Çocuğun cinsel istismarı (TCK, m. 103) suçu çerçevesinde değerlendirilmesi gerekir.

Ancak, 18.6.2014 tarihli ve 6545 sayılı Kanununla TCK'nın cinsel suçlara ilişkin hükümlerinde ve özellikle m. 105, f. 1'de yapılan değişiklikler karşısında, on beş yaşını tamamlamamış olan çocuğa karşı fiziki temas olmadan gerçekleştirilen cinsel davranışların da, Cinsel taciz suçunu oluşturacağı yönünde bir izlenim ortaya çıkmıştır.

15 yaşını tamamlamıș çocuğun kaçırılmış olması, bu çocuğa karşı cebir, tehdit, hile veya iradeyi etkileyen başka bir nedenle direnemeyecek duruma getirilmiş olduğunu göstermektedir.

Türk Ceza Kanununun ilk düzenlemesinde, on beş yaşını tamamlamış olan ve fakat, cebir, tehdit, hile veya iradeyi etkileyen başka bir nedenle direnemeyecek duruma getirilmiş çocuğa karşı fiziki temas olmadan gerçekleştirilen cinsel davranışlar da, Çocuğun cinsel istismarı suçunu oluşturmakta idi.

Ancak, 2014 yılında 6545 sayılı Kanunla TCK'nın cinsel suçlara ilişkin hükümlerinde ve özellikle m. 105, f. 1'de yapılan değişiklikler, on beş yaşını tamamlamış olan ve fakat, cebir, tehdit, hile veya iradeyi etkileyen başka bir nedenle direnemeyecek duruma getirilmiş çocuğa karşı fiziki temas olmadan gerçekleştirilen cinsel davranışların da, Cinsel taciz olarak değerlendirilmesinin yolunu açmıştır.

Nitekim, Yargıtay 14. Ceza Dairesinin değerlendirme konusu yaptığımız kararında, bu düşünce benimsenmiştir. Kararda, kaçırılmış ve bu nedenle artık direnemeyecek duruma getirilmiş olan çocuğa karşı fiziki temas olmadan gerçekleştirilen cinsel davranışlar da Cinsel taciz suçu olarak nitelendirilmiştir.

Oysa, TCK, m. 103, f. 1, bent b düzenlemesi karşısında, on beş yaşını tamamlamış olan, 
Buna göre, TCK, m. 103, f. 1, bent a kapsamına giren çocuklara karş1 gerçekleştirilen, fiziksel temas olsun veya olmasın, her türlü cinsel davranış, cinsel istismar olarak değerlendirilmelidir. Buna karşılık, TCK, m. 103, f. 1, bent b kapsamına giren, on beş yaşını tamamlamış ve maruz kaldığ1 fiilin hukuki anlam ve sonuçlarını algılama yeteneği gelişmiş olan çocuğa karş1 "cebir, tehdit, hile veya iradeyi etkileyen başka bir nedene dayalı olarak" ve fiziksel temas suretiyle "gerçekleştirilen cinsel davranışlar", cinsel istismar olarak değerlendirilmelidir. Bu itibarla, TCK, m. 105, f. 1'de söz konusu edilen cinsel taciz suçunun nitelikli halinin mağduru, ancak TCK, m. 103, f. 1, bent b kapsamına giren, on beş yaşını tamamlamış ve maruz kaldığ fiilin hukuki anlam ve sonuçlarını algılama yeteneği gelişmiş olan çocuk olabilecektir. Ancak bu suretle, TCK, m. 103, f. 1'deki cinsel istismar suçunun tanımı ile, m. 105, f. 1'de söz konusu edilen cinsel taciz suçunun mağdur bakımından nitelikli unsurunu birbiriyle uyumlu, telifi kabil bir şekilde yorumlamak mümkün olabilir.

4. $5237 \mathrm{~s}$. TCK'nın sisteminde, henüz on beş yaşını doldurmamış olan çocukla cinsel ilişki alelıtlak, cinsel istismar suçunu (TCK, m. 103) oluşturmaktadır. Ancak, bu suçun faili olabilmek için, kişinin on beş yaşını doldurmuş olması gerekir. On beş yaşını henüz doldurmamış olan kişilerin birbirleriyle cinsel ilişkiye girmeleri bağlamında bu kişilerin ceza hukuku sorumluluğu yoluna gidilemez. Ancak, bu çocukların cinsel birlikteliğini sağlayan kişilerin cinsel istismar suçundan (TCK, m. 103) dolayı ceza hukuku sorumluluğu yoluna gidilmesi gerekir.

5. On beş yaşını doldurmuş olan çocuklar cinsel özelliklerinin ve yeteneklerinin farkında olmakla birlikte, kişiliklerinin henüz yeterince gelişmemiş olması,

temyiz gücü bulunan ve fakat, cebir, tehdit, hile veya iradesini etkileyen başka bir nedenle direnemeyecek duruma getirilmiş çocuğa karşı fiziki temas olmadan gerçekleştirilen cinsel davranışların, cinsel taciz değil, cinsel istismar suçunu oluşturduğunu kabul etmek gerekir.

Çocuğun cinsel istismarı suçunu oluşturduğunun kabul edilmesi halinde, soruşturma ve kovuşturmasının şikayete bağlı olmadığı açıktır.

Olayda hangi suçun işlendiği kabul edilirse edilsin, ister çocuğun cinsel istismarı suçu, ister cinsel taciz suçunun işlendiği kabul edilsin, suç tamamlanmıştır. Çocuk, istek doğrultusunda çamaşırlarını çıkarmaya başlamıştır. Çamaşırlarını tamamen çıkarmış olup olmaması, olay bağlamında oluştuğu kabul edilen suçun tamamlanması için önem taşımamaktadır.

Olayda A ve B'yi her iki suçtan dolayı müşterek failler olarak sorumlu tutmak gerekir. Özellikle ikinci suç bakımından B'nin araç dışına çıkarak beklemesi de, bu suçtan dolayı yardım eden sıfatıyla değil, müşterek fail sıfatıyla sorumluluğunu gerektirmektedir. Zira, fiilin işlenişi üzerinde A ve B müşterek hakimiyet tesis etmişlerdir. 
başkalarıyla cinsel ilişkiye girmenin sonuçlarını yeterince kavrayacak bir sorumluluk duygusuna sahip olmamaları dolayısıyla; bu kişilerle rızaen cinsel ilişkiye girmek, ayrı bir suç olarak tanımlanmıştır (TCK, m. 104, f. 1). Başka bir deyişle, yeni TCK, on beş yaşını tamamlamamış olan çocuklara, bir başkasıyla cinsel ilişkide bulunmak yönünde cinsel bütünlükleri üzerinde tasarrufta bulunma yetkisi tanınmamıştır. Bu nedenle, on beş yaşını tamamlamış olan çocuğun rıza açıklaması, reşit kılınmadığı sürece, kendisiyle cinsel ilişkide bulunan bir başkasının fiilini hukuka uygun hale getirmemektedir ${ }^{3}$.

\footnotetext{
3 On beş yaşını tamamlamış olan çocuklarla cinsel iliş̧iye giren kişi hakkında soruşturma ve kovuşturma yapılabilmesi için, mağdurun şikayette bulunması gerekir. Bu itibarla, mağdurun şikayette bulunmaması veya bilahare şikayetten vazgeçmiş olması, fiili hukuka uygun hale getirmemektedir. Bir ceza muhakemesi hukuku müessesesi olan şikayet, sadece bir soruşturma ve kovuşturma koşulu oluşturmaktadır.
}

Anayasa Mahkemesinin 8.3.2018 tarihli ve 2014/15959 bireysel başvuru sayılı Kararına konu teşkil eden olayda; başvurucu, vücudundaki gelişme ve değişikliklerden şüphelenmesi üzerine, 9.4.1996 doğumlu kızı F'yi 27.7.2013 tarihinde doktora götürerek muayene ettirir. Bu muayenede F'nin yaklaşık yedi aylık hamile olduğu anlaşılır. F'nin, 2012 yılının Kasım ayından beri kendisinden birkaç yaş büyük olan A ile arkadaş olduklarını ve bu arkadaşlık sürecinde müteaddit defa cinsel ilişkiye girdiklerini anne ve babasına anlatması üzerine, ailesinden kişiler, A ve ailesinden sair kişilerle görüşerek bu duruma bir çözüm bulmaya çalışırlar. Ancak, bu arada F, 28.7.2013 tarihinde intihar eder.

Başvurucu, A'nın tutum ve davranışlarıyla kızı F'yi intihara yönlendirdiğini iddia ederek, hakkında suç duyurusunda bulunur. Soruşturma kapsamında yapılan DNA testinde, F'nin hamile kaldığı ceninin babasının A olduğu anlaşılır.

Manavgat Cumhuriyet Başsavcılığı tarafından; F'nin cinsel birliktelik yaşadığı tarihlerde on beş yaşından büyük ve A ile cinsel ilişkisinin rızaya dayalı olması karşısında, cinsel istismar suçunun oluşmadığı; reşit olmayanla cinsel ilişki suçu bakımından ise şikayette bulunulmadığı için A hakkında soruşturma ve kovuşturma yapılmasının mümkün olmadığı; A'nın F'yi intihara yönlendirme suçunu işlediği yönündeki iddianın dayandığı somut ve objektif delil bulunmadığı gerekçesiyle, kovuşturmaya yer olmadığı kararı verilir.

"Başvurucu baba; kızının hamile olduğunu, dolayısıyla cinsel ilişkiyi kendisinin öğrendiğ tarihten itibaren süresinde yaptı̆̆ şikayet üzerine kovuşturma başlatılmamasından şikayetçidir." (pn. 55)

Ancak Anayasa Mahkemesi, aşağıdaki gerekçelerle başvurucunun söz konusu olayda mağdur sıfatını haiz olmadığı ve şikâyet hakkını kullanamayacağı yönünde karar vermiştir:

“"Reşit olmayanla cinsel ilişsi” "suçu, 5237 sayılı Kanun'da "kişilere karşı suçlar” l hüküm altına alan ikinci kısmın "Cinsel Dokunulmazlığa Karşı Suçlar” başlı̆̆l altında düzenlenmektedir. Suçun basit halinin takibi şikayete tabidir. Şikayet hakkı ise kişiye sıkı surette bağll bir hak olup korunan hukuki değerin sahibi olan çocuğa aittir. Ayırt etme gücüne sahip (sezgin) küçükler, mağduru oldukları suç yönünden doğrudan doğruya şikayet hakkına sahiptirler. Çocuğun kanuni temsilcisi olmaları nedeniyle ebeveynlerinin de şikayet hakkı bulunmaktadır. Ancak ebeveynin şikayet hakk suçun mağduru çocuğun şikayet hakkından bağımsız bir hak değildir. Ebeveyn ile çocuğun iradelerinin çatışması durumunda çocuğun iradesine üstünlük tanınmaktadır." (pn. 56) 
Ancak bu suçun failinin çocuk olmaması gerekir. Bu itibarla, on beş yaşını

\begin{abstract}
"Başvuruya konu olayda, reşit olmayanla cinsel ilişki suçu yönünden bizzat müteveffa tarafindan hak düşürücü süre içinde yapılmış bir şikayet bulunmaması nedeniyle ceza takibatının mümkün olmadığına karar verilmiștir. Mă̆duru olduğu suç yönünden doğrudan doğruya şikayet hakkına sahip olan müteveffanın hak düşürücü süre içinde fiil ve faili bilmesine karşın cezai takip yapılması yönünde bir irade beyan etmediği anlaşılmakta olup bireysel başvuru yapma yönünde bir iradesi oluştuğundan da söz edilemeyecektir." (pn. 57)

"Kişiye sıkı surette bağlı olan, cinsel dokunulmazliğa karşı suçlar arasında yer alan reşit olmayanla cinsel ilişki suçunun etkili şekilde soruşturulmadığı iddiası yönünden başvurucunun şikayetin konusundan doğrudan etkilenmiş olduğu, başka bir ifade ile bireysel başvuru anlamında mağdur olduğu söylenemez." (pn. 58)
\end{abstract}

\title{
Hukuki değerlendirmelerimiz:
}

TCK, m. 104, f. 1'de tanımlanan "Reşit olmayanla cinsel ilişski” suçu bakımından bir soruşturma ve kovuşturma şartı olan şikayet, mağdur veya suçtan zarar gören tarafından kullanılabilir. Söz konusu suçun mağduru, fiilin işlendiği tarih itibarıyla on beş yaşını tamamlamış olan ve fakat reşit olmayan kız veya erkek çocuktur; başka bir ifadeyle, mümeyyiz, işlediği fiilin hukuki anlam ve sonuçlarını algılama yeteneği gelişmiş olan kız veya erkek çocuktur. Bu nedenle söz konusu suç bakımından F, şikayet hakkını kullanabilir. Ancak, F’nin şikayet hakkını kullanabilmesi için, son fiilin işlendiği yani son cinsel birleşmenin meydana geldiği tarihten itibaren altı ayın geçmemesi gerekir. Her ne kadar F yedi aylık hamile ise de, A ile arasında müteaddit defa cinsel ilişkinin gerçekleşmiş olması dolayısıyla, son cinsel birleşme tarihinin belirlenip, şikayet hakkının kullanılması bakımından sürenin geçip geçmediğini buna göre tespit etmek gerekir (Aynı yönde bkz. Anayasa Mahkemesinin 11.5.2016 tarihli ve 2013/3262 bireysel başvuru sayılı kararı, pn. 103 [RG. 12 Ekim 2016/29855]).

Kanuni temsilci ancak temyiz (ayırt etme) gücüne sahip bulunmayan çocukla ilgili olarak şikayet hakkını haizdir. Örneğin sarkıntılık düzeyinde kalmış cinsel istismar suçunun failinin de çocuk olması halinde soruşturma ve kovuşturma yapılması şikayete bağlı kılınmıştır (TCK, m. 103, f. 1, dördüncü cümle). Başka bir ifadeyle, sarkıntılık düzeyinde kalmış istismar suçunun çocuk tarafından işlenmesi halinde, bu fail hakkında ancak şikayet üzerine soruşturma ve kovuşturma yapılabilecektir. Çocuk tarafindan işlenen sarkıntılık düzeyinde kalmış cinsel istismar suçunun mağduru, henüz on beş yaşını tamamlamamış olan veya tamamlamış olmakla birlikte maruz kaldığı fiilin hukuki anlam ve sonuçlarını algılama yeteneği gelişmemiş olan çocuk olduğu için, şikayet hakkı bu çocuğun kanuni temsilcisi, yani velisi veya vasisi tarafından kullanılabilir. (Temyiz gücüne sahip bulunmayan mağdur çocukla ilgili şikayet hakkının veli veya vasi tarafından kullanılacağı hususunda bkz. Yargıtay CGK, 2.12.2014, E. 2014/3-28, K. 2014/537).

Buna karşılık temyiz gücüne sahip bulunan çocuk, mağduru olduğu suçtan dolayı şikayet hakkını ancak kendisi kullanabilir. Bu çocuğun yerine kanuni temsilcinin şikâyet hakkı bulunmamaktadır (Temyiz gücüne sahip mağdur çocuğun şikayet hakkını bizzat kullanabileceği hususunda bkz. 15.4.1942 tarihli ve 14/9 sayılı Yargıtay İçtihadı Birleştirme Kararı; Yargitay CGK, 2.3.2004, E. 2004/2-44, K. 2004/58). Temyiz gücüne sahip olup olmamanın, fiilin işlendiği tarih itibarıyla değil, şikayetin yapıldığı tarih itibarıyla dikkate alınması gerekir.

İşaret etmek gerekir ki, hukuk sistemimizde, temyiz gücüne sahip olsun veya olmasın, çocuğun mağduru olduğu suçtan dolayı açılan kamu davasında kanuni temsilciye (veli veya vasiye), bu sıfatı dolayısıyla davaya katılma yetkisi verilmemektedir (Bkz. CMK, m. 237 vd.). Özellikle temyiz gücüne sahip bulunmayan mağdur çocuklar bakımından bunun önemli bir 


\section{doldurmuş olmakla birlikte henüz on sekiz yaşını doldurmamış olan kişilerin}

eksiklik oluşturduğunu düşünmekteyiz. Dikkat edilmelidir ki, mümeyyiz olmayan mağdur çocuğun kanuni temsilcisi tarafından davaya katılma yönünde talepte bulunulması ve bu talebin kabulü halinde, katılan sıfatını haiz olan kanuni temsilci değil bizzat çocuk olmaktadır (Bkz. Yargitay CGK, 13.3.2018, E. 2015/14-136, K. 2018/98).

Uygulamamızda, mümeyyiz çocuğun mağduru olduğu şikayete bağl1 suçtan dolayı kanuni temsilcinin "şikayeti" üzerine de soruşturma başlatılabilmektedir. Bu durumda, kanuni temsilcinin "şikayet"ini ihbar olarak değerlendirmek gerekir. Bu ihbar üzerine başlatılan soruşturmada ilk yapılması gereken iş, mümeyyiz çocuğun ifadesi alınarak, şikayet hakkını kullanıp kullanmadığının kendisine sorulmasıdır.

Mümeyyiz çocuk, şikayet hakkını kullanmak istemezse ya da bilahare şikayetten vazgeçerse, artık kanuni temsilcinin "şikayet"ine itibar edilerek soruşturma ve kovuşturmaya devam edilemez. Bu itibarla, her ne kadar mümeyyiz çocuğun mağduru olduğu suçtan dolayı kanuni temsilcinin ihbarı üzerine soruşturma ve kovuşturma başlatılsa da, çocuğun şikayet hakk1nı kullanmaması veya şikayette bulunmakla birlikte bilahare şikayetini geri alması halinde, soruşturma evresinde kovuşturmaya yer olmadığı kararı, kovuşturma evresinde ise düşme kararı verilmesi gerekir.

Ancak uygulamamızda, temyiz gücüne sahip bulunan çocuğun mağduru olduğu suçtan dolayı bizzat şikayet hakkını kullanabileceği kabul edilmekle birlikte, şikayetten vazgeçebilmesi için, kanuni temsilcisinin muvafakati aranmıştır (Bkz. Yargıtay 5.CD, 7.7.2003, E. 2002/5666, K. 2003/4359).

Veli veya vasi, ancak mümeyyiz olmayan çocuğun mağduru olduğu suçtan dolayı bu çocuğun kanuni temsilcisi sıfatıyla şikayet hakkını haizdir. Bu durumda veli veya vasi, suçun mağduru kendisi olmadığ 1 için, bu sıfatla şikayet hakkına sahip değildir.

Kanuni temsilci olarak veli veya vasi, TCK, m. 104, f. 1'de tanımlanan "Reşit olmayanla cinsel ilişski" suçunun mağduru değildir. Bu nedenle söz konusu suçla ilgili olarak şikayet hakkını haiz değildir. Yukarıda da belirtildiği gibi, kanuni temsilcinin bu konudaki "şikayet"ini ihbar olarak değerlendirmek gerekir. Bu çerçevede, Anayasa Mahkemesinin söz konusu bireysel başvuru kararında iki ihtimal düşünülebilir.

Birinci ihtimal olarak; şikayet hakkını kullanmamış olan F, şikayet süresini geçirdikten sonra ölür. Bu durumda, kanuni temsilcinin ihbarına istinaden soruşturma başlatılmış olsa bile, ihbar konusu suç, şikayete bağlı bir suç olduğu için, kovuşturmaya yer olmadığı kararının verilmesi gerekir.

İkinci ihtimal olarak; F, mağduru olduğu suçla ilgili olarak şikayet hakkını kullanmadan ve şikayet süresi henüz geçmeden ölür. TCK, m. 104, f. 1'de tanımlanan suçun mağduru, mümeyyiz (temyiz, ayırt etme gücüne sahip) olduğu için, daha açık ifadeyle, işlediği fiilin hukuki anlam ve sonuçlarını algılama yeteneğine sahip bulunduğu için, ancak kendisi şikayet hakkını haizdir. Bu ihtimalde de kanuni temsilcinin şikayet hakkından bahsetmek mümkün değildir. Belirtilen nedenle, bu ihtimalde de, kanuni temsilcinin ihbarı üzerine başlatılan soruşturmada kovuşturmaya yer olmadığı kararının verilmesi gerekir.

Söz konusu olayda, mağdur F'nin intiharı ile, ölüm öncesinde yaşadığı olaylar arasında doğal bir oldu olarak nedensellik ilişkisi kurulması mümkündür. Ancak, her ne kadar F yaşadığı olayların etkisiyle intihar etme yönünde bir tercihte bulunmuş ise de, intihar etmek suretiyle gerçekleşen ölüm neticesini A'ya veya başka herhangi birine objektif olarak isnat etmek, hukuken mümkün değildir. 
birbiriyle olan karşılıklı rızaya dayalı cinsel ilişkileri, ceza hukukunun müdahale alanı dışında kalmalıdır ${ }^{4}$. Bu grup yaş küçükleri arasındaki cinsel ilişki sorunu, ancak toplum ve aile disiplini çerçevesinde çözümlenebilir ${ }^{5}$.

6. Aralarında evlenme yasağı bulunan kişiler arasındaki rızaya dayalı cinsel (ensest) ilişki, bir haksızlık oluşturmakla birlikte, özel hayat alanı içinde gerçekleştiği sürece, ceza hukukunun müdahale alanı dışında tutulmuştur. Ancak, on beş yaşını tamamlamış olan çocukla rızaya dayalı ensest ilişki, suç olarak tanımlanmıştır. Bu bağlamda madde gerekçesinde şu açıklamalara yer verilmiştir ${ }^{6}$ :

"Maddeye eklenen ikinci fikrayla, birinci fikrada tanımlanan suçun, arasında evlenme yasağ bulunan kişiler tarafindan işlenmesi halinde şikâyet aranmaksızın, altı yıldan onbeş yıla kadar hapis cezast verilmesi düzenlenmektedir. "Ensest" ilişkilerin, birinci fikrada tanımlanan suça nazaran daha ă̆ır cezayı gerektiren ve soruşturulması veya kovuşturulması şikâyete bağlı olmayan bir suç olarak tanımlanması suretiyle, bu suçla daha etkin mücadele edilebilmesi ve çocukların cinsel sömürüsünün engellenmesi amaçlanmaktadır.

Bu düzenlemeye bağll olarak, rızaya dayalı da olsa onbeş yaşının doldurmamış olan çocuklarla olan ensest ilişkinin, 103'üncü maddede tanımlanan çocukların cinsel istismarı suçu bakımından daha ağır cezayı gerektiren nitelikli unsur oluşturduğu göz önünde bulundurulmalıdır."

III. Tüm bu bilgiler 1şığında, yukarıda özetlemiş olduğumuz Anayasa Mahkemesinin 10.10.2019 tarihli ve 2015/17914 başvuru numaralı Bireysel Başvuru Kararına konu teşkil eden olayda işlenen suçlar şunlardır:

4 Kimin fail, kimin mağdur olduğunu belirleme imkanı bulunamayan bir suç tanımı olamaz. Bu nedenle, söz konusu suç ancak on sekiz yaşını doldurmuş olan kişiler tarafindan işlenebilir. Buna göre, söz konusu suçun faili, on sekiz yaşını doldurmuş olan bir kişi; mağduru ise, on beş yaşını doldurmuş olmakla birlikte henüz on sekiz yaşını doldurmamış olan bir kişi olabilir. Madde metninin hukuk biliminin gereklerine uygun olarak yapılan bu yorumuna göre, fail veya mağdurun cinsiyeti önemli değildir.

Ancak bu yorum biçimi itibarıyla madde metninde aranan şikâyet şartının kimin tarafından gerçekleştirileceğinin de hukuki bakımdan izahı mümkün olabilir.

5 Ayrıntılı bilgi için bkz. ÖZGENÇ, İzzet: Türk Ceza Hukuku Genel Hükümler, Ceza Hukukuna Giriş, Suç Teorisi, Yaptırım Teorisi, Milletlerarası Ceza Hukuku, 15. bası, Ağustos 2019, sh. 380 vd.; Türk Ceza Hukuku Mevzuatı, cilt 1 (Kanunlar), 24. bası, sh. 292; ÖZGENÇ, İzzet: Türk Ceza Kanunu Gazi Şerhi, 3. bası, Ankara, Ocak 2006 (Adalet Bakanlığı yayını), m. 104 altında yer alan açıklamalar.

TBMM, Yasama Dönemi: 24, Yasama Y111: 4, Sıra Sayısı: 592, sh. 22. 
Birinci suç: $E \rightarrow M$, Çocukların cinsel istismarı suçu (TCK, m. 103, f. 1, bent a).

M henüz on dört yaşındadır. E'ye karşı on beş yaşını tamamlayıncaya kadar cebir veya tehdide gerek olmadan fiziksel temasla gerçekleştirilen cinsel davranışlar, cinsel istismar suçunu oluşturur.

E ile $\mathrm{M}$ arasında üçüncü derecede kayın hısımlığı mevcuttur. Fail ile mağdur arasındaki akrabalık ilişkisine dayanan bu nitelikli unsur nedeniyle, E hakkında TCK, m. 103, f. 1'e göre belirlenen temel ceza f. 3, bent c hükmüne istinaden yarı oranında artırılacaktır.

Maruz kaldığı bu fiiller sebebiyle M'nin psikolojisinin bozulması ve eğitimine devam edememesi, cinsel istismar suçunun temel şeklinden dolay1 TCK, m. 103, f. 1, birinci cümle hükmüne göre verilecek olan temel cezanın belirlenmesinde dikkate alınır.

Dikkat edilmelidir ki, karardan anlaşıldığı kadarıyla, E, gerçekleştirdiği cinsel davranışlar kapsamında $\mathrm{M}$ ile cinsel ilişkide bulunmamıştır.

Cinsel istismar fiilleri müteaddit defa işlendiğine göre, $\mathrm{E}$ hakkında bu suçtan dolayı zincirleme suç (TCK, m. 43, f. 1) hükümlerini uygulamak gerekir.

İkinci suç: $\mathrm{E} \rightarrow \mathrm{M}$, Cinsel taciz suçu (TCK, m. 105, f. 1).

TCK'nın cinsel suçlara ilişkin hükümlerinde değişiklik yapan $6545 \mathrm{~s}$. Kanunun esas aldığı düşünceye göre, E’nin M'ye karşı fizikî temas olmaksızın gerçekleştirdiği cinsel davranışlar, $M$ ile yaptığı telefon görüşmeleri sırasında kullandığ1 ifadeler, cinsel istismar suçu çerçevesinde değerlendirilmeyip, cinsel taciz suçunu oluşturacaktır.

$\mathrm{Bu}$ suç, çocuğa karşı işlenmiştir. Mağdurun sıfatı itibarıyla bir nitelikli unsur söz konusudur (TCK, m. 105, f. 1).

Keza, söz konusu suç, telefonla görüşme suretiyle yani "elektronik haberleşme araçlarının sağladığı kolaylıktan faydalanmak suretiyle" işlenmiştir (nitelikli unsur: TCK, m. 105, f. 2, bent d).

Ayrıca M'nin, maruz kaldığı bu fiiller sebebiyle eğitimine devam edememesi, cinsel taciz suçu bakımından bir neticesi sebebiyle ağırlaşmış hal oluşturmaktadır. $\mathrm{Bu}$ durumda cinsel taciz suçundan dolayı verilecek olan temel cezanın alt sınırı bir yıldan az olamaz (TCK, m. 105, f. 2, son cümle). 
Söz konusu fiilleri müteaddit defa işlediğine göre, E hakkında cinsel taciz suçundan dolayı zincirleme suç (TCK, m. 43, f. 1) hükümlerini uygulamak gerekir.

Oysa, yukarıda açıkladığımız kanaatimiz çerçevesinde, E'nin gerek fizikî temas suretiyle gerek telefon görüşmeleri sirasında kullandığ 1 ifadeler itibarıyla henüz on beş aşını tamamlamamış olan M'ye karşı gerçekleştirdiği bütün bu fiillerin, cinsel istismar suçunu oluşturduğunu kabul etmek gerekir.

Bu itibarla, olayda ayrıca cinsel taciz suçu oluşmamıştır ve cinsel istismar suçunun yanı sıra ayrıca cinsel taciz suçundan dolayı mahkûmiyet hükmünün kurulmasina gerek yoktur.

Üçüncü suç: $\mathrm{E} \rightarrow \mathrm{M}$, Tehdit suçu (TCK, m. 106, f. 1, birinci cümle)

Henüz on beş yaşını tamamlamamış olan kişiye karşı cinsel istismar suçunun cebir veya tehdit kullanılarak işlenmesi, bu suç bakımından bir nitelikli unsur olarak belirlenmiştir (TCK, m. 103, f. 4).

E, M'yi olup bitenleri başkasına anlatmaması ve olayın açığa çıkmaması için tehdit etmiştir. Ancak, bu tehdit olgusunun, zincirleme surette devam eden cinsel istismar fiillerinin işlenişi bakımından mağdurun direncini kırma yönünde bir etki meydana getirme özelliği taşıdığının da dikkate alınması gerekir. Bu durumda, farklı neviden fikri içtima (TCK, m. 44) hükümlerini dikkate alarak, E hakkında, ayrıca tehdit suçundan dolayı hüküm kurmak yerine, cinsel istismar suçundan dolayı verilecek olan cezanın TCK, m. 103, f. 4 hükmüne istinaden artırılması yoluna gitmek gerekir.

Olayda E'nin ayrıca tehdit suçundan dolayı TCK, m. 106, f. 1, birinci cümle hükmüne istinaden cezalandırılması yoluna gidilmiş olsaydı; tehdit fiillerinin müteaddit defa işlenmiş olması itibarıyla, E hakkında bu suçtan dolayı da zincirleme suç (TCK, m. 43, f. 1) hükümlerini uygulamak gerekirdi.

Şayet E, M'nin on beş yaşını tamamlamasından sonra da bu fiillerine devam etmiş olsaydı, bu durumda E'nin fiillerini değişik perspektiflerden ele alıp değerlendirmek gerekir.

E'nin on beş yaşını tamamlamış olan M'ye karşı gerçekleştirdiği fiillerin cinsel istismar suçu çerçevesinde değerlendirilebilmesi için, cebir, tehdit, hile veya iradeyi etkileyen başka bir nedene dayalı olarak gerçekleştirilmesi gerekir.

E, her defasında M'yi olup bitenleri başkasına anlatmaması ve olayın açığa çıkmaması için tehdit etmiştir. Yukarıda da belirtildiği gibi, bu tehdit 
olgusunun, zincirleme surette devam eden cinsel davranışların gerçekleştirilişi bakımından mağdurun direncini kırma yönünde bir etki meydana getirme özelliği taşıdığını da dikkate almak gerekir. Bu durumda, E’nin M'ye karşı gerçekleştirdiği cinsel davranışların on beş yaşını tamamladıktan sonra devam edenleri de cinsel istismar suçunu oluşturmaya devam eder (TCK, m. 103, f. 1 , bent b).

$\mathrm{Bu}$ durum, söz konusu suçla ilgili olarak zincirleme suç hükümlerinin uygulanmasinda dikkate alınır.

E'nin cinsel ilişkiye varmayan bu cinsel davranışlarına M tarafindan rıza gösterildiğinin kabul edilmesi halinde, bu cinsel davranışlar hukuka aykırılık özelliğini kaybetmez, fakat suç oluşturmaz. Zira, TCK, m. 104, f. 1'de tanımlanan suçu oluşturan fiil, cinsel ilişkidir.

$\mathrm{E}$, on beş yaşını tamamladıktan sonra $\mathrm{M}$ ile rızaen cinsel ilişkide bulunmuş olsaydı, M'nin bu yöndeki rızasının hukuki geçerliliği olmayacağı için, fiili reşit olmayanla cinsel ilişsi (TCK, m. 104) suçunu oluşturacaktı. Bu durumda, M'nin teyzesiyle evli olduğu için E bakımından bir evlenme engeli mevcuttur. Ancak, bu engele rağmen, $M$ ile $E$ arasında bir evlenme yasağı bulunmamaktadır. Zira, Türk Medeni Kanununa göre, "kayın hisımlığ meydana getirmiş olan evlilik sona ermiş olsa bile, eşlerden biri ile diğerinin üstsoyu veya altsoyu arasında" evlenme yasaklanmıştır. (m. 129, bent 2). Bu nedenle, belirtilen durumda TCK, m. 104, f. 2 hükmü uygulama kabiliyetini haiz değildir.

E'nin, henüz on beş yaşından küçük iken cinsel bakımdan istismar etmeye başladığı M'nin on beş yaşını tamamlamasından sonra da bu fiillerine rızaen cinsel ilişkide bulunmak suretiyle devam etmesi halinde, zincirleme olarak işlenen fiiller önce cinsel istismar suçunu, bilahare ise, reşit olmayanla cinsel ilişki suçunu oluştururdu. Bu ihtimalde, hafiften daha ağıra doğru değil, ağırdan daha hafife doğru işleyen bir süreç söz konusudur. Her iki suçu oluşturan fiiller, aynı suç işleme kararının icrası kapsamında işlenmiştir. Her ne kadar, mağdurun on beş yaşını tamamlamasından sonraki fiiller, cinsel istismar suçunu değil de, reşit olmayanla cinsel ilişki suçunu oluştursa bile; işlenen fiillerin doğal mahiyetinde bir değişiklik bulunmamaktadır. Bu nedenle olayda, E hakkında cinsel istismar ve reşit olmayanla cinsel ilişki suçlarından dolayı ayrı ayrı cezaya hükmetmek (gerçek içtima) yerine, zincirleme suç hükümlerini uygulayarak, sadece cinsel istismar suçundan dolayı hüküm kurulmasının ve bu suçtan dolayı verilen cezanın TCK, m. 43, f. 1 hükümlerine göre artırılmasının, daha doğru olacağını 
düşünmekteyiz?

IV. Olayda E'nin M'ye yönelik cinsel davranışları devam ederken, anne A durumdan haberdar olmuştur; fakat buna kayıtsız kalmıştır.

Olayda zincirleme şekilde "işlenmekte olan bir suç" söz konusudur. İşlenmekte olan bir suçu yetkili mercilere bildirmemek, TCK, m. 278'de tanımlanan "Suçu bildirmeme" suçunu oluşturur. A, bu suçu işlemiştir.

Söz konusu suç bakımından olayda, bir nitelikli unsur gerçekleşmiştir. Bildirimi ihmal edilen suçun mağdurunun on beş yaşının bitirmemiş bir çocuk olması, suçu bildirmeme suçu bakımından daha ağır cezayı gerektiren bir nitelikli unsurdur (TCK, m. 278, f. 3).

Ancak, Söz konusu olayda A ile cinsel istismar suçunun faili E arasında ikinci dereceden kayın hısımlığı mevcuttur. Ceza Muhakemesi Kanununa göre, "şüpheli veya sanığın üçüncü derece dâhil kan veya ikinci derece dahil kayın hısımları" tanıklıktan çekinebilirler (CMK, m. 45, f. 1, bent d).

Kanunda, tanıklıktan çekinebilecek olan kişilerle ilgili olarak suçu bildirmeme suçu bağlamında bir şahsi cezasızlık sebebi kabul edilmiştir (TCK, m. 278, f. 4).

A ile eniştesi E arasında ikinci dereceden kayın hısımlığı mevcuttur.

Ancak, anne A'nın henüz on dört yaşını tamamlamamış olan kızı M ye karşı işlenen cinsel istismar fiillerinden haberdar olmasına rağmen duruma kayıtsız kalması, ayrıca velayet ilişkisinden kaynaklanan bakım ve gözetim yükümlülüğünün ihlali mahiyeti taşımaktadır. Bu velayet ilişkisi dolayısıyladır ki, anne A, kızı M'ye karşı işlenen cinsel istismar suçunun işlenişini önlemekle yükümlüdür. Bu yükümlülüğün yerine getirmemesi dolayısıyla A, E'nin icrâ davranışlarla M'ye karşı işlediği cinsel istismar suçuna ihmali davranışla iştirak etmiş̧ir.

Nitekim, TCK, m. 278, f. 4, ikinci cümlede, "suçu önleme yükümlülü̆g̈̈nün varllğı dolaylsıyla ceza sorumluluğuna ilişkin hükümler saklı" tutulmuştur.

Bu durumda, A, E'nin M'ye karşı işlediği cinsel istismar suçuna yardım eden (şerik) (TCK, m. 39) sıfatıyla iştirakten dolayı sorumlu tutulmalıdır ${ }^{8}$.

7 Ayrıntılı bilgi için bkz. ÖZGENÇ, Türk Ceza Hukuku Genel Hükümler, 15. bası, sh. 618, dn. 1123.

8 Ayrıntılı bilgi için bkz. ÖZGENÇ, İzzet: Suç Örgütleri, 12. bası, Ankara, Ocak 2019, sh. 
V.Türk Medeni Kanununa göre, "erkekveya kadın onyedi yaşını doldurmadıkça evlenemez. Ancak, hâkim olağanüstü durumlarda ve pek önemli bir sebeple onaltı yaşını doldurmuş olan erkek veya kadının evlenmesine izin verebilir." (m. 124).

Keza, "kayın hisımlığl meydana getirmiş olan evlilik sona ermiş olsa bile, eşlerden biri ile diğerinin üstsoyu veya altsoyu arasinda" evlenme yasaklanmıştır (Türk Medeni Kanunu, m. 129).

Yukarıda da belirtildiği gibi, E'nin evli olması ve M'nin yaşının küçük olması bir evlenme engeli oluşturmakla birlikte; aralarında evlenme yasağı söz konusu olmadığı için, bilahare E'nin boşanması ve M'nin de evlenme yaşına gelmesi halinde, evlenebilirler.

Ancak bu evliliğin, E’nin M'ye karşı işlemiş bulunduğu suçlardan dolayı ceza sorumluluğu üzerinde bir etkisi bulunmamaktadır.

VI. Adalet Bakanlığının gündeminde olan bir kanun çalışmasında, cinsel suç mağdurlarıyla faillerinin bilahare "evlenmeleri", "evlendirilmelerinin sağlanması" halinde, ceza soruşturma ve kovuşturmalarının veya en azından, hükmolunan cezanın infazının durdurulması ve bilahare de tamamen ortadan kaldırılması yönünde bir kanuni düzenleme yapılması istenmektedir.

Siyaseti ve emrindeki bürokrat "hukukçu"ları bu şekilde bir kanuni düzenleme yapma ihtiyacı hissettiren, değiştirilmesi için akademisyen sıfatıyla bütün girişimlerimize rağmen, Yargıtay'ın ısrarlı bir şekilde sürdürdüğü yanlış uygulamalar olmuştur.

$\mathrm{Bu}$ yanlış uygulamaların arka planındaki zihniyeti anlamak için, 1 Haziran 2005 tarihinde yürürlükten kaldırılan 765 sayılı Türk Ceza Kanununun İNSANLIK DIŞI 434. maddesi hükmünün ve bu hükmün uygulanmasına ilişkin örnek içtihatları tekrar gündeme getirmek ihtiyacı doğmuştur.

Söz konusu 434. madde hükmü aynen şöyleydi:

"Kaçırılan veya alıkonulan kız veya kadın ile maznun veva mahkûmlardan biri arasında evlenme vukuunda, koca hakkında hukuku âmme dâvası ve hüküm verilmiş ise, cezanın çektirilmesi tecil olunur.

Müruruzaman haddine kadar erkek tarafindan haksız olarak vukua 
getirilmiş bir sebeple boşanmaya hükmedilirse takibat yenilenir. Evvelce hüküm verilmiş ise ceza çektirilir.

\section{Bu madde hükümleri 414, 415 ve 416'ncı maddeler hakkında da caridir.}

\section{Evlenen maznun veya mahkûm hakkında hukuku âmme dâvasının veya cezanın tecilini müstelzim olan hâller, fiilde methali olanlar hakkında dâva ve cezanın düşmesini müstelzimdir."}

$\mathrm{Bu}$ düzenlemeye ilişkin 11.6.1936 tarihli ve 3038 sayılı Kanunun "gerekçe"sinde şu açıklamalara yer verilmişti:

"Kız ve kadın kaçırma hadiselerinde, kaçırılan kız veya kadın ile maznunun evlenmesi halinde takibat tecil olunur ve hüküm sadır olmuş ise ceza çektirilmez. Fakat bunun için bir şart vardır. Kız veya kadın on sekiz yaşını geçmiş ise kendisinin ve bu yaştan aşağı ise velisinin davadan vazgeçmiş olması lazımdır. Evlenme vuku bulmasına rağmen, kız veya kadının yaşı on sekizden aşağı olduğu için bu hususta kanuni selâhiyeti haiz olan velisi davadan vazgeçmez ise takibat devam eder. Ceza verilmiş ise hüküm infaz olunur. Bu hal, bir kere teessüs etmiş olan bir ailenin huzurunu selbetmesi itibariyle tecviz olunamayacağ gibi, on beş yaşını bitirmiş olan küçüklerin evlenmelerinde hakimin izni şart olmasına (Kanunu Medeni, madde 88) ve evlenme kişiyi reşit kılacağına (Kanunu Medeni, madde 11) nazaran, evlenmiş olan bir kızın veya kadının kocası lehine davadan vazgeçmemesi kanunlarımız arasında kabili telif olmayacak şekilde bir tezat vücuda getirmektedir. Bu sebeplerle 434. madde değiştirilmiştir."

Dikkat edilmelidir ki, her ne kadar söz konusu maddenin birinci fikrası ve gerekçesi "kaçırılan veya alıkonulan kız veya kadın"dan söz etmekte ise de; özellikle üçüncü fikrası hükmü dikkate alındığında, bu hükmün yaşı ne olursa olsun, "Irza tecavüz"e uğrayan, cinsel saldırı ve cinsel istismar suçlarının mağdureleri bakımından uygulama kabiliyetini haiz olduğu açık bir şekilde anlaşılır.

Söz konusu madde hükmü, 1889 İtalyan Ceza kanununun 352. maddesi hükmünden iktibas edilmişti.

Buna göre, "Irza tecavüz"e uğrayan mağdure ile sanıklardan biri arasında "evlenme"nin sağlanması halinde, devam etmekte bulunan soruşturma ve 
kovuşturma "evlenen" erkek ${ }^{9}$ bakımından durdurulurdu ${ }^{10}$, diğer suç ortakları bakımından ise, düşerdi yani kapatılırdı" . "Evlenen" erkeğin haksız olarak boşanmaya neden olması halinde, soruşturma ve kovuşturmaya kaldığı yerden devam olunuyordu ${ }^{12}$. Ancak dava ile ilgili olarak düşme kararı verilmişse, artık yapılacak bir şey kalmamaktaydı.

Mahkûmiyet hükmü kesinleşmiş ise, "evlenen" erkek bakımından cezanın infazı ertelenirdi ${ }^{13}$. Ceza zamanaşımının dolması halinde, mahkûmiyet "vaki olmamış" sayılıyordu. Ceza zamanaşımı dolmadan önce, erkeğin haksız olarak boşanmaya neden olması halinde, ceza infaz edilirdi.

İştirakhalinde işlenen "ırza tecavüz" suçlarında, mağdurenin suçortaklarından herhangi biriyle "evlenmesi" sağlandığı takdirde, diğer bütün suç ortakları bakımından dava veya ceza düşmekteydi, yani soruşturma ve kovuşturma tamamen, bir daha açılmamak üzere kapatılmakta; hükmolunan ve kesinleșen ceza da vaki olmamış sayılmakta idi ${ }^{14}$. "Evlenen" erkek bilahare mağdureyi haksız bir şekilde boşasa bile, artık diğer suç ortakları bakımından soruşturma ve kovuşturmaya devam edilemez ve hükmolunan ceza infaz edilemezdi ${ }^{15}$.

Belirtmek gerekir ki, insanlık dışı bu madde hükmü, Anayasa Mahkemesi tarafindan da hukuki olmayan gerekçelerle hukuka ve Anayasaya "uygun" bulunmuştu ${ }^{16}$.

9 “Irza tecavüz” suçunun kadın tarafından örneğin henüz 14 yaşını doldurmamış olan erkek çocuğa karşı işlenmesi halinde, bu madde hükmü uygulanmıyordu.

10 Yargitay 5. Ceza Dairesi, 26.2.2007; 1356/1510.

11 Bu durumda yargılama gideri de sanıklara yükletilmemekteydi: Yargıtay 5. Ceza Dairesi, 15.4.1985, 1671/1564; ayn1 Daire, 25.1.2001; 3815/182; ayn1 Daire, 26.11.1998, 3828/4500.

12 Açılan boşanma davasında, karşılıklı kusurun varlığı kabul edilerek boşanmaya karar verilmesi halinde, "evlenen" erkek hakkında "Irza tecavüz" suçundan dolayı açılmış ve durma kararı verilmiş olan davaya devam edilerek beraat kararı verilmesi gerekiyordu. Bkz. Yargitay 5. Ceza Dairesi, 17.5.1985, 1933/2179; aynı Daire, 5.12.2000, 8387/6758; aynı Daire, 22.3.1999, 5302/1078; ayn1 Daire, 22.10.1998, 3325/3848.

$13 \mathrm{Bu}$ durumda söz konusu mahkûmiyet hükmü tekerrüre de esas teşkil etmemekte idi.

14 Bkz. Yargitay 5. Ceza Dairesi, 16.11.2000, 2446/6256; ayn1 Daire, 24.6.1999, 1847/3281; ayn1 Daire, 21.6.1999, 1884/3162; ayn1 Daire, 23.10.1998, 3331/3811; 7.10.1998, $3230 / 3551$.

15 Majno, Ceza Kanunu Şerhi, Cilt III, Ankara, 1980, sh. 196.

16 Anayasa Mahkemesi’nin 9.10.1997 tarihli ve E. 1996/77, K. 1997/64 sayılı Kararı (RG: 18 Haziran 1998/23376). 
Aynı hüküm, Türk Ceza Kanununa ilişkin Hükümet (Dönmezer) Tasarısında da dili güncellenmek suretiyle yer almakta idi:

"Dava veya cezanin ertelenmesini gerektiren etkin pişmanlık

Madde 327- Kaçırılan veya alıkonulan ile sanık veya hükümlülerden biri evlendiğinde, mahkemece fail hakkındaki kamu davası ve hüküm verilmis ise cezanın çektirilmesi ertelenir.

Evlenme tarihinden itibaren beş yıl içinde, fail tarafindan haksız olarak meydana getirilmiş bir nedenle boşanmaya hükmedilirse, kovuşturma yenilenir; evvelce hüküm verilmiş ise ceza çektirilir.

Bu madde hükümleri 315 ilâ 318 inci maddelerde yazll suçlar ("Zorla ırza geçme", "Zorla ırza tasaddi" gibi suçlar) hakkında da uygulanır.

Evlenen sanık veya hükümlü hakkında kamu davasının ve cezanın ertelenmesini sonuçlandıran haller, failin suç ortakları hakkında kamu davasının ve cezanın düşmesini gerektirir."

Madde gerekçesinde özellikle son fikra hükmüyle ilgili olarak yer verilen açıklamalar, bu düzenlemeyle önemli bir suiistimal kapısının açık tutulduğunun işaretlerini taşımakta idi:

"Son fikrada, evlenen sanık veya hükümlüler hakkında kamu davasının veya cezanin ertelenmesini gerektiren hâllerin, fiilde ortak olanlar hakkındaki kamu davası veya cezanın düşmesini gerektireceği hükmüne yer verilmiştir. Dolaylsıyla sonradan boşanma olsa bile adı geçenler hakkındaki kovuşturma yenilenmeyecek, cezanın infazına girişilmeyecektir."

Yargıtay'ın 1srarlı talebine rağmen, 5237 sayılı yeni Türk Ceza Kanununda bu veya benzeri madde hükmüne yer verilmemiştir.

$\mathrm{Bu}$ bağlamda uygulamamızda yaşanan sorunların esas kaynağı Yargıtay uygulamamızdır. Yargıtay, bu bağlamda yaşanan sorunların çözümüne yönelik olarak TCK, m. 30, f. 4’te düzenlenen haksızlık hatasına ilişsin hükümleri uygulamamakta 1srarc1 tutumunu devam ettirmektedir.

Açıkça belirtmek gerekir ki, cinsel istismar suçunun bir çocuk tarafından cebir, tehdit veya hile olmaksızın işlendiği durumlarda, özellikle çocuk fail bakımından TCK'nın haksızlık hatasına ilişkin hükümlerini uygulamak gerekir. 
Aşağıdaki Yargıtay kararları, sorunun kaynağını ortaya koyduğu gibi, açıklamaya çalıştığımız ve savunduğumuz çözüm yolunun haklılığını teyit etmektedir.

Karar no 1: Yargitay Ceza Genel Kurulu'nun 15.9.2015 tarihli ve E. 2013/14749, K. 2015/277 sayılı kararına konu teşkil eden olayda 22.6.1993 doğumlu Gözde, aynı köyde doğmuş ve kendisinden birkaç yaş büyük olan Mehmet ile arkadaştırlar. $\mathrm{Bu}$ arkadaşlıkları zamanla duygusal arkadaşlığa dönüşür, 2008 y1lında evlenmek amaciyla birlikte kaçarlar ve aralarında müteaddit defa cinsel birleşme gerçekleşir.

Ceza Genel Kurulu, çocuk yaşta olan (üçüncü grup yaş küçüğü) Mehmet'in, 14 yaşından gün alan ve fakat bu yaşı henüz tamamlamayan Gözde ile cinsel ilişkiye girmesi fiili bağlamında,

"sanığın mağdureyi uzun süredir tanıması ve ailesinin yaşı küçük olduğu için evlenmelerine izin vermediğini bilmesi karşısında, mă̆durenin onbeş yaşından küçük olduğunu bilmemesi hayatın olağan akışına aykırı olup somut olayda TCK'nun 30. maddesinde düzenlenen hata halinin uygulanma şartları mevcut değildir"

gerekçesiyle, Esas Mahkemesinin Mehmet hakkında verdiği çocuğun cinsel istismarı suçundan (TCK, m. 103) mahkumiyet hükmünün onanmasına karar vermiştir.

Dikkat edilmelidir ki, dosyada Gözde ile Mehmet'in bilahare 10.7.2011 tarihinde evlenmiş olduklarına ve bu birlikteliklerinden, birincisi evlilik öncesinde 21.7.2010 tarihinde, ikincisi ise evlilik birliği içinde 20.5.2014 tarihinde dünyaya gelmiş iki çocuk sahibi olduklarına dair bilgi mevcuttur. Başka bir ifadeyle Ceza Genel Kurulu, Mehmet hakkında hükmolunan 5 yıl 6 ay 20 gün hapis cezasının onanması yönünde karar verirken bu bilgilere vakıftır.

Karara konu teşkil eden olayda, mercilerce Mehmet tarafindan suçun maddi unsurlarında, yani Gözde'nin yaşı ile ilgili olarak, hataya düşülüp düşülmediği tartışma konusu yapılmıştır. Bu tartışmanın arkasındaki düşünceye göre, şayet Mehmet on beş yaşını tamamlamış olduğunu zannederek Gözde ile cinsel birliktelik gerçekleştirmiş ise, cinsel istismar suçuna ilişkin olarak kastı bulunmamaktadır. Bu durumda Mehmet'in fiilini TCK, m. 104, f. 1 kapsamında değerlendirmek gerekecektir. Somut olayda Gözde'nin şikayeti olmadığı için Mehmet'in cezalandırılması cihetine gidilemeyecektir.

Burada sorun, bir kast sorunu değildir. Bu tür olaylarda fail, cinsel birliktelik 
gerçekleştirdiği mağdurenin henüz on beş yaşını tamamlamadığını bilebilir. Ancak, fail, mağdurenin yaşının küçük olduğunu bilmesine rağmen, fiziki yapıs1 itibarıyla cinsel bütünlüğ̈̈ üzerinde tasarrufta bulunma olgunluğuna eriştiğini düşünerek hareket etmiş olabilir. Somut olayda fail mağdureyle olan cinsel birlikteliğini içinde yaşadığı toplum telakkileri itibarıyla "meşruiyet" zeminine oturtma çabası içindedir. Nitekim fail, mağdurenin Türk Medeni Kanunu hükümlerine göre 16 yaşını tamamlaması üzerine mahkemeye başvurarak yargı kararıyla reşit kılınmasını sağlamış ve bilahare de mağdure ile Türk Medeni Kanunu hükümlerine göre akdedilen nikâhla evlenmiştir.

$\mathrm{Bu}$ durum karşısında, aralarında sadece birkaç yıl yaş farkı bulunan failin, mağdureyle cinsel birlikteliği bağlamında gerçekleştirdiği fiilin haksızlık oluşturduğunun bilincinde olmadığını ve bu konudaki hatasının kaçınılmaz olduğunu kabul etmek gerekir.

Fail ile mağdure arasında evlilik birliğinin gerçekleşmiş olmasına ve bu cinsel birliktelikten dünyaya gelmiş iki çocuğun bulunmasına rağmen, artık reşit kılınmış eş bakımından koca, dünyaya gelmiş iki çocuk bakımından baba olmanın sorumluluğunu taşıyan kişinin mahkum olduğu 5 yıl 6 ay 20 gün hapis cezasının kesinleşmesini sağlayan, Ceza Genel Kurulu'nun oy çokluğuyla verdiği söz konusu karar, hukukla izah edilemez.

Türk yargısı bu çerçevede ortaya çıkan sorunları, failin kastı bağlamında tartışarak bir sonuca bağlamaya çalışırken, TCK, m. 30, f. 4'de düzenlenen haksızlık hatası bağlamında değerlendirmeye yanaşmamaktadır. Söz konusu hukuki sorunun çözümüyle ilgili olarak Türk yargısının bu çekingenliği, egemen siyaseti bu sorunun, hukuki olmayan başka uygulamalara sebebiyet vermesi pahasına da olsa, yasama faaliyetiyle çözümlenmesi arayışlarına sevk etmiştir ve etmektedir.

Karar no 2: Yargitay Ceza Genel Kurulu'nun 5.11.2013 tarihli ve E. 2013/14573, K. 2013/432 sayılı Kararına konu teşkil eden olayda; 18.10.1992 doğumlu olan M, S ile tanışıp arkadaşlık yapmaya başlar ve aralarında evlenmeye karar verirler. 2007 yılı Haziran ya da Temmuz ayında cinsel ilişkiye girerler. M'nin hamile olduğunun anlaşılması üzerine $\mathrm{S}$ ile birlikte kaçmaya karar verirler ve 7.8.2007 tarihinde kaçarak birlikte yaşamaya başlarlar.

M ile S, daha sonra ailelerin araya girmesi sonucu "imam nikahı" yaparak evli gibi birlikte yaşamaya devam ederler.

$\mathrm{Bu}$ olayla ilgili olarak Yargıtay Ceza Genel Kurulu, aşağıdaki içtihatta bulunmuştur: 
“Kanun koyucu 5237 sayılı TCK'nın 103. maddesinde üç grup mă̆dura yer vermiştir. Birincisi onbeş yaşını tamamlamamış olan çocuklar, ikincisi onbeş yaşını tamamlamış olmakla birlikte fiilin hukuki anlam ve sonuçlarını algılama yeteneği gelişmemiş olan çocuklar, üçüncüsü ise onbeş yaşını tamamlayıp onsekiz yaşını tamamlamamış çocuklardır. Birinci ve ikinci grupta yer alan çocuklara karşı cebir, tehdit, hile veya iradeyi etkileyen başka bir neden olmaksızın dahi gerçekleştirilen her türlü cinsel davranış istismar suçunu oluşturmakta, eylemin bu kişilere karşı cebir veya tehdit kullanılmak suretiyle gerçekleştirilmesi ise anılan maddenin dördüncü fikrası uyarınca cezanın yarı oranında artırılmasını gerektirmektedir. Üçüncü grupta yer alan çocuklar yönüyle eylemin (TCK, m. 103'te tanımlanan çocukların cinsel istismar1 suçunu) oluşturmast için gerçekleştirilen cinsel davranışların cebir, tehdit, hile veya iradeyi etkileyen başka bir nedene dayalı olarak gerçekleştirilmesi gerekmektedir. Nitekim cebir, tehdit ve hile olmaksızın onbeş yaşını bitirmiş olan çocukla cinsel ilişkide bulunan kişi, anılan Kanunun 103. maddesinde düzenlenmiş olan çocukların cinsel istismarı suçundan değil, şikayet üzerine 104. maddede düzenlenen reşit olmayanla cinsel ilişki suçundan cezalandirilacaktır.

Fail, cinsel ilişkide bulunduğu mağdurenin 15 yaşını doldurmadığ halde, 15 yaşını doldurduğu düşüncesiyle măgdure ile rızasıyla cinsel ilişkide bulunur ve şikayetçi olmayan mă̆durenin yaşı konusundaki hatası esasl, diğer bir ifadeyle kabul edilebilir bir hata olursa, bu takdirde fail 5237 sayıl TCK'nun 30. maddesinin birinci fikrası uyarınca suçun maddi unsurlarından olan mağdurun yaşına ilişkin bu hatasından yaralanacak, bunun sonucu olarak yüklenen suç açısından kasten hareket etmiş sayılmayacă̆ından ve bu suçun taksirle işlenmesi hali kanunda cezalandırılmadığından 5271 sayılı CMK'nun 223. maddesinin ikinci fikrasının (c) bendi gereğince beraatına karar verilmesi gerekecektir. ...

S ile M, aynı okulda öğrencidirler. Yaklaşık bir yıl süreyle arkadaşlık yaparlar. Lise üçüncü sınıf öğrencisi olan $S$, kendisi ile birlikte aynı okulda lise birinci sınıf öğrencisi olan M'nin 15 yaşından küçük olduğunu bilmektedir.

Bu nedenle, onbeş yaşını tamamlamamış olan Mile zincirleme şekilde rızasılyla cinsel ilişkide bulunan ve M'yi alıkoyan S'nin çocukların cinsel istismarı ve kişiyi hürriyetinden yoksun kılma suçlarından ayrı ayrı cezalandırılmasına ilişkin yerel mahkeme karart isabetlidir." 
Söz konusu olayda M'nin henüz on beş yaşını tamamlamamış olduğunu S'nin bildiği kabul edilebilir. S, M'nin on beş yaşını tamamladığını da düşünebilir. Mağdur bakımından özellikle birkaç ay ve hatta birkaç gün sonra on beş yaşın tamamlanacağı durumlarda, bu hatadan söz edilebilir. Mağdurun yaş1 konusunda hatanın olup olmadığı her somut olayın şartlarına göre belirlenecek olan bir husustur.

Bu gibi durumlarda sorunu, gerçekleştirdiği fiil bakımından failin bir haksızlık hatasına düşüp düşmediği sorunu olarak ayrıca ele almak gerekmektedir.

Karara konu teşkil eden olayda mağdure lise birinci sınıfta öğrencidir; fail de aynı lisede son sınıf öğrencisidir. İlk Derece Mahkemesi ve Ceza Genel Kurulu, bu olayda failin mağdurenin yaşı konusunda hataya düştügünü kabul etmemiştir.

Karar no 3: Yargitay Ceza Genel Kurulu'nun 25.2.2014 tarihli ve E. 2013/14349, K. 2014/ 96 sayılı kararına konu teşkil eden olayda 19.6.1992 tarihinde Çorum Devlet Hastanesinde doğan M, B ile arkadaş olur. Duygusallığın da eşlik ettiği bu arkadaşlıkta B, M'yi 17.6.2007 tarihinde anne ve babası ile birlikte kaldığı eve götürür ve arasında cinsel ilişki gerçekleşir.

$\mathrm{Bu}$ fiil sebebiyle $\mathrm{B}$ ile anne ve babası hakkında cinsel istismar suçunu işledikleri iddiasıyla kamu davası açılır. B, savunmalarında M'nin yaşının küçük olduğunu bilmediğini ileri sürer.

İlk derece mahkemesi bul olayda B hakkında çocuğun cinsel istismarı suçundan TCK, m. 103, f. 2, m. 62 ve m. 53 hükümleri uyarınca 6 y1l 8 ay hapis; kişiyi hürriyetinden yoksun kılma suçundan TCK, m. 109, fikra 1, fikra 3 bent $\mathrm{f}$, fikra 5, m. 62 ve m. 53 hükümleri uyarınca 2 yıl 6 ay hapis; babası A ve annesi $H$ hakkında çocuğun cinsel istismarı suçuna yardım eden sıfatıyla iştirakten dolayı 3 y1l 4 ay hapis; kişiyi hürriyetinden yoksun kılma suçuna yardım eden sıfatıyla iştirakten dolayı 1 yıl 3 ay hapis cezasına hükmetmiştir (Çorum Ağır Ceza Mahkemesi, 4.12.2007, 227-287).

Yargıtay 14. CD ise, söz konusu mahkumiyet hükmünü çeşitli gerekçelerle bozmuştur (14. CD, 11.12.2012, 6358-12851). Konumuzla ilgili olarak Özel Daire kararında,

"suç tarihinde 14 yaş 11 ay 28 günlük olan mağdure ile sanık B'nin anlaşıp birlikte kaçarak B'nin ailesi ile birlikte yaşadiğı eve geldikleri ve burada rizalarlyla cinsel ilişkiye girdikleri, daha sonra resmi olarak evlendikleri ve bir çocuklarının olduğu olayda, B'nin aşamalardaki 
ifadelerinde, suç tarihinde mağdurenin kendisine 16 yaşında olduğunu söylediğini ve onu 16 yaşında olarak bildiğini beyan etmesi karşısında, TCK'nın 30. maddesi hükümleri yönünden hata halinin mevcut olup olmadı̆̆ının tespiti için mağdurenin görünüm itibarıyla 15 yaşından küçük olduğunun anlaşılıp anlaşılamayacağl, içinde bulundukları sosyal ve kültürel durumları, saniğın ulaşmak istediği amaç ile mağdurun içinde bulunduğu sonuç da dikkate alınarak sanığın mağdurenin yaşı konusunda hataya düşmesinin mümkün olup olmadiğg araştırılarak ve mahkemenin dosyadaki tüm verilerle birlikte kendi gözlemini de tespit ederek, gerekirse bu konuda bilirkişi incelemesi de yaptırılarak sonucuna göre sanıkların hukuki durumlarının takdir ve tayini gerekirken eksik inceleme ile yazılı şekilde hüküm kurulması,"

hukuka aykırı bulunmuştur.

Bu bozma kararına Yargıtay Cumhuriyet Başsavcıllı̆̆ itiraz etmiştir (20.2.2013, 154666). İtiraz gerekçesinde;

"765 sayll mülga Türk Ceza Kanunundaki 434. madde benzeri bir düzenlemenin 5237 sayll Türk Ceza Kanununda bulunmaması karşısında, aile birliğini sağlamaya matuf bir uygulamanın hukuki olmaktan ziyade vicdani olarak değerlendirildiği kanaati uyandırmaktadır. Aynı durumda olup da resmi evlilik gerçekleştirmeyen sanıklar yönünden haksızlık oluşturabilecek bu uygulama, cinsel saldırı veya çocukların cinsel istismarı suçunu cebir veya tehdit ile gerçekleştiren sanıklar açısından da uygulanabilirliği düşünüldügü̈nde, bu nitelikteki suçlart işleyenlerin daha az ceza almaları veya eylemlerinin şikayete bağl suça dönüşme ihtimali karşısında, adaletsiz ve kamu vicdanını zedeleyen kararların verilmesine yol açabileceği düşünülmelidir"

şeklinde açıklamalara yer verilmiştir.

Yargıtay Ceza Genel Kurulu, bu olayda “ $B$ 'nin suç tarihi itibariyle on beş yaşııı ikmal etmesine iki gün kalmış olan M'nin on beş yaşından büyük olduğunu düşünmesi hayatın olağan akışına uygun olup, mağdurenin suç tarihinde fiziki görüntüsü itibariyle onbeş yaşından büyük olup olmadiğının tespiti ile sonucuna göre sanıları hukuki durumunun belirlenmesi gerektiğinden, yerel mahkeme hükmünün, somut olayda 5237 sayıl TCK'nun 30. maddesinin uygulanma şartlarının bulunup bulunmadı̆̆ının belirlenmesi gerektiğinden 
bahisle bozulmasına ilişkin Özel Daire kararı"nı doğru bulmuştur ${ }^{17}$.

Karar no 4: Yargitay Ceza Genel Kurulu'nun 2.6.2015 tarihli ve E. 2014/1447, K. 2015/178 sayılı Kararına konu teşkil eden benzer olayda; 1.6.1992 günü hastane doğumlu olarak dünyaya gelen ve lise birinci sınıf öğrencisi olan ondört yaşını tamamlamamış olan Neşe ile kendisinden dokuz yaş büyük Erdal bir buçuk yıllık arkadaşlığın ardından birçok kez cinsel ilişkiye girerler; Neşe'nin hamile kalması üzerine evlenmek isterler; ancak Neşe'nin yaşının küçük olması nedeniyle resmî nikah işlemlerini yapamazlar; ardından dini nikâhla evlenip Erdal'ın anne ve babasının evinde birlikte yaşamaya başlarlar.

Neşe 16.5.2007 tarihinde bir çocuk dünyaya getirir ve çocuk Erdal'ın nüfusuna kaydedilir. Bilahare Neşe ve Erdal, 10.2.2009 tarihinde resmi nikâhla evlenirler.

Bu olayda Tekirdağ 2. Ağır Ceza Mahkemesi Erdal hakkında;

a) Çocuğun cinsel istismarı suçunun nitelikli halini müteselsilen işlediğini kabul ederek, TCK, m. 103, f. 2; m. 43, f. 1 ve m. 62 hükümleri uyarınca sekiz yıl dört ay hapis cezasına,

b) Kişiyi hürriyetinden yoksun kılma suçunu işlediğini kabul ederek, TCK, 109, f. 1, 3, 5 ve m. 62 hükümleri uyarınca, ayrıca iki yıl altı ay hapis cezasına, hükmetmiştir.

Yargitay 14. Ceza Dairesi ise, Erdal'ın Neşe'nin yaşına ilişkin olarak hataya düşüp düşmediğinin araştırılmadığ bozmuştur.

Ancak, Yargıtay Cumhuriyet Başsavcılığ 1 , bu bozma kararına itiraz etmiştir. Başsavcıllğın görüşüne göre, Neşe'nin yaşına ilişkin olarak Erdal'ın "kaçınılmaz" bir hatası söz konusu değildir.

Ceza Genel Kurulu, bu olayda TCK, m. 30'da düzenlenen hata hükümlerinin uygulanma şartlarının mevcut olmadığı ve failin, çocuğun cinsel istismarı (TCK, m. 103) ve kişiyi hürriyetinden yoksun kılma (TCK, m. 109) suçlarından cezalandırılması yönünde kurulan mahkumiyet hükmünün hukuka uygun olduğu değerlendirmesinde bulunmuştur.

Birinciolaydan farklı olarak, bu olayda failin, mağdureile arasındakiyaş farkının fazlalığı karşısında, gerçekleştirdiği fiilin haksızlık oluşturduğu hususundaki

17 Anayasa Mahkemesi de, 25.3.2015 tarihli ve 2014/6419 sayılı bireysel başvuru sayılı kararında, aynı yönde değerlendirmelerde bulunmuştur. 
hatasının kaçınılabilir olduğu değerlendirmesinde bulunulmalıdır.

Karar no 5: Yargitay Ceza Genel Kurulu'nun 13.12.2016 tarihli ve E. 2016/14941, K. 2016/1236 sayılı Kararına konu teşkil eden olayda; NŞ, kendisinden 11 yaş küçük olan, 19.7.2000 doğumlu, lise birinci sınıf öğrencisi M ile 2013 yılında duygusal yönü olan arkadaşlık kurar ve bu arkadaşlık sürecinde M ile cinsel ilişkiye girer.

İlk derece mahkemesi bu olayda NŞ hakkında çocuğun cinsel istismarı suçundan TCK, m. 103, f. 2; m. 43, f. 1; m. 62; m. 53 hükümleri uyarınca 16 yıl 8 ay hapis cezasına hükmetmiştir (Bakırköy 10. Ağır Ceza Mahkemesi, 3.3.2015, 12-42)

Yargıtay 14. CD ise, söz konusu mahkumiyet hükmünü onamıştır (14. CD, 2.12.2015, 5771-11238).

Yargıtay Cumhuriyet Başsavcıllı̆ı, bu olayda failin, mağdurenin yaş1 konusunda hataya düştüğünü, mağdurenin fiziki görüntüsü itibarıyla 15 yaşını tamamlamış olduğunu zannederek fiili işlediğini savunması karşısında, suçun maddi unsurlarında hata hükümlerinden (TCK, m. 30, f. 1) yararlanmas1 gerektiği gerekçesiyle bu onama kararına itiraz etmiştir (31.1.2016,180197).

Yargitay Ceza Genel Kurulu ise, İlk derece mahkemesinin hükmünü ve Yargitay 14. Ceza Dairesinin onama kararını doğru bularak, Yargıtay Cumhuriyet Başsavcılı̆̆ının itirazını reddetmiştir ${ }^{18}$.

18 Buna karşılık, Yargıtay 14. Ceza Dairesinin 10.4.2017 tarihli ve E. 2014/8911, K. 2017/1941 sayılı Kararına konu teşkil eden olayda; 10.12.1985 doğumlu A ile amcasının kızı olan 1.9.1996 doğumlu B'nin, ailelerinin muvafakatiyle ve 10.11.2008 tarihinde "imam nikâhı" ile "evlilikleri" sağlanır. B, bu birliktelikten hamile kalır. B'nin bu hamilelik sürecinde başvurduğu hastanede, hamileliğinin henüz on dört yaşını doldurmadan önce gerçekleştiğinin ortaya çıkması üzerine, Cumhuriyet Başsavcılığına suç duyurusunda bulunulur.

Kahramanmaraş Devlet Hastanesinde yaşı ile ilgili olarak düzenlenen Kurul Raporunda, olayın meydana geldiği tarih (10.11.2008) itibarıyla B'nin “yaklaşı 12 yaş 10 aylık” olduğu" tespitinde bulunulmuştur.

Bunun üzerine A hakkında "çocuğun cinsel istismarı" suçunu zincirleme olarak işlediği iddiasıyla kamu davası açılmıştır.

Dava sürecinde Mahkemece başvurulan Adli Tıp Kurumu 2. İhtisas Kurulunun düzenlediği Rapora göre ise, B'nin 9.4.2009 tarihi itibarıyla, "13 yaşını bitirmiş olup, 14 yaşın içerisinde olduğu" tespit ve değerlendirmesinde bulunulmuştur.

Söz konusu dava sürecinde B’nin anne ve babasının, "mağdur" olarak ifadeleri alınmıştır.

A, yapılan sorguları sırasında olayın meydana geldiği tarih itibarıyla B’nin “yaşının 17 olduğunu" zannederek fiili işlediğini ileri sürmüştür.

İlk derece mahkemesinde yapılan yargılama sonucunda, A'nın, B'nin yaşına ilişkin hataya düştüğ̈̈ ve bu hatasının kastını ortadan kaldırdığı kabul edilerek, beraatine hükmedilmiştir. 


\section{Sonuç}

Hukuk uygulamamızda cinsel suçlar bağlamında çeşitli sorunların olduğu bilinen bir husustur. Cinsel suçlarla ilgili olarak Kanunda öngörülen cezaların ağırlı̆̆ı, cinsel suç faillerinin özellikle infaz sürecinde gözetim ve denetiminin sağlanması, önemli bir sorundur. Bunun dışında, özellikle cinsel istismar suçunun mağduru ile failinin bilahare "evlendirilmeleri" bağlamındaki sun'î "sorunun", geçici madde şeklinde de olsa, kanuni düzenlemeyle "çözümlenmesine" çalışılması, ancak yeni sorunların ortaya çıkmasına sebebiyet verir ${ }^{19}$.

Yargıtay 14. Ceza Dairesi, söz konusu beraat kararını onamıştır.

19 İşaret etmek gerekir ki, Anayasa Mahkemesi de suç failinin istismar suçunun mağduru ile bilahare evlenmesinin ceza hukuku sorumluluğu üzerinde etkisinin olmadığını, işlenen fiilin haksızlık muhtevasını ortadan kaldırmadığını, dolaylı bir şekilde kabul etmiştir: 18.4.2019 tarihli ve 2016/30913 bireysel başvuru say1l Karar; 6.12.2017 tarihli ve 2014/1214 bireysel başvuru sayılı Karar. 
Ankara Hacı Bayram Veli Üniversitesi Hukuk Fakültesi Dergisi C. XXIV, Y. 2020, Sa. 1 